\title{
Cutaneous Hepatic Porphyria and Oestrogens
}

\author{
P. W. MONCKTON COPEMAN,* M.B., M.R.C.P.; D. J. CRIPPS, †M.B.; R. SUMMERLY, $\ddagger$ M.B., M.R.C.P., M.R.C.P.ED.
}

Brit. med. F., 1966, 1, 461-463

Study of the response of the various porphyrias to drugs contributes to the understanding of their dissimilar biochemistry and pathogenesis (De Matteis and Rimington, 1962 ; Rimington, 1964). The cutaneous hepatic porphyria that develops in a very limited number of chronic alcoholics has definite biochemical features. It has been reported that oestrogens may precipitate or aggravate this variety of porphyria (Watson, 1960, 1964 ; Watson et al., 1962 ; Wilkinson, 1963 ; Hurley and English, 1963 ; Theologides et al., 1964) ; which, if true, might suggest a biochemical defect in alcoholic cutaneous hepatic porphyria similar to that present in acute intermittent porphyria-a disease known to be influenced adversely by female sex hormones.

The cases of two patients who developed alcoholic cutaneous hepatic porphyria while receiving oestrogens for carcinoma of the prostate are described. We investigated the effect of oestrogen therapy on the levels of porphyrins in the blood and excreta of these two patients, and in six non-alcoholic patients with carcinoma of the prostate who had been taking stilboestrol in high dosage for a number of years. In neither group did the oestrogens affect the porphyrin levels.

\section{Case 1}

A retired labourer aged 81 presented with a six-month history of an eruption of tense bullae, circular ulcers, crusting, and scarring with patchy depigmentation on the areas exposed to light-bald pate, face, back of neck, and dorsa of hands and fingers. Cutaneous hepatic porphyria was diagnosed on clinical and histological grounds. The eruption had developed one month after prostatectomy for carcinoma of the prostate. (There were still no signs of metastases two years later.) The following drugs were given to him in hospital at the time of the prostatectomy: for anaesthesia, intravenous barbiturate (thiopentone), $400 \mathrm{mg}$., suxamethonium $50 \mathrm{mg}$., gallamine $80 \mathrm{mg}$; ; on one occasion only promethazine $50 \mathrm{mg}$. intramuscularly, glutethimide $500 \mathrm{mg}$., Pamergan (atropine, pethidine, promethazine), and bendrofluazide $5 \mathrm{mg}$.; Pethilorphan (pethidine, levallorphan) $75 \mathrm{mg}$. four doses. He was discharged on caps. chlorotrianisene (Tace) $12 \mathrm{mg}$. b.d. There was no family history of a similar condition. He had been a healthy man who for about 30 years of his working life had drunk up to 14 pints (8 litres) of beer a day.

On presentation he had no fever, no neurological or abdominal disturbance, and the liver and spleen were not felt. He had hypertension (210/180-120/100), radiological cardiomegaly, and a regular pulse rate of $60-90$.

Investigations.-Routine blood examination, urine examination, and chest $x$-ray picture were normal. Liver-function tests: bromsulphalein test-less than $5 \%$ retention after 45 minutes; serum proteins-raised $\gamma$-globulin level. Serum acid and alkaline phosphatases were normal. Porphyrin results (Table I): porphyrins and porphyrin precursors were estimated over three periods-(1) before, (2) during, and (3) after stopping the oestrogens.

\section{Case 2}

A retired naval engineer aged 72 presented with an eruption of cutaneous hepatic porphyria that had developed eight months after

* St. Thomas's Hospital, London. Present address: Westminster Hospital, London.

† St. John's Hospital for Diseases of Skin, London. Present address : Department of Dermatology, University of Wisconsin Medical Centre, Madison, Wisconsin, U.S.A.

‡ St. Thomas's Hospital, London. Present address: M.R.C. Unit, Experimental Pathology of Skin, University of Birmingham Medical School, Birmingham. prostatectomy and orchidectomy for carcinoma of the prostate. At that time he had received the following drugs: barbiturate (thiopentone) and suxamethonium for anaesthesia, and barbiturates and pethidine post-operatively. Since then he has taken stilboestrol $5 \mathrm{mg}$. daily, and also sulphamethizole $600 \mathrm{mg}$., which had been stopped a few weeks before he presented. The family history was negative. His only living relative, a male first cousin aged 55, had normal porphyrin excretion.

Past Medical History.- He had had angina pectoris for 20 years, treated with glyceryl trinitrate and more recently with pentaerythritol tetranitrate and dipyramidole. He claimed "moderate" alcoholic intake for many years and one to two bottles of sherry daily more recently. He had wintered in Spain for four months each year.

On presentation he had the characteristic bullous scarring eruption on exposed parts, leuconychia, pigmentation, and gynaecomastia. The liver edge was palpable (two fingerbreadths) and firm. The spleen was not felt. There was no evidence of metastases one and a half years after the prostatectomy.

Investigations.-The following were normal: serum acid and alkaline phosphatase, blood urea, blood Wassermann reaction, stool examination for occult blood, serum proteins, serum bilirubin, thymol flocculation, thymol and zinc sulphate turbidity tests. $X$-ray pictures of chest and skeleton were normal. Bromsulphalein retention test: $8 \%$ of the dye was retained after 45 minutes.

Liver Biopsy.-Histological abnormalities demonstrated (Dr. P. J. Scheuer): patchy fatty change, vascular dilatation, and some mononuclear infiltration in portal regions. Porphyrin fluorescence was noted.

Table I.-Case 1. Six Months' Observation (25 February to 27 August 1964)

\begin{tabular}{|c|c|c|c|c|c|c|c|c|c|c|}
\hline \multirow{2}{*}{$\begin{array}{l}\text { Date } \\
1964\end{array}$} & \multirow{2}{*}{$\begin{array}{l}\text { Chloro- } \\
\text { trian- } \\
\text { isene }\end{array}$} & \multicolumn{4}{|c|}{$\begin{array}{c}\begin{array}{c}\text { Urine } \\
\text { (mg./day) }\end{array} \\
\end{array}$} & \multicolumn{3}{|c|}{$\begin{array}{c}\text { Stools } \\
(\mu \mathrm{g} . / \mathrm{g} . \text { Dry Wt. }) \\
\end{array}$} & \multicolumn{2}{|c|}{$\begin{array}{c}\text { Plasma } \\
(\mu \mathrm{g} . / 100 \mathrm{ml})\end{array}$} \\
\hline & & P.B.G. & A.L.A. & $\mathrm{Cp}$ & Ur & $\mathrm{Cp}$ & $\mathbf{P p}$ & Ur & $\mathrm{Cp}$ & Ur \\
\hline $\begin{array}{r}25 / 2 \\
26 / 2 \\
14 / 4 \\
15 / 4 \\
16 / 4 \\
21 / 4 \\
23 / 4 \\
1 / 5 \\
\end{array}$ & $\begin{array}{l}\text { Yes } \\
\text { ”, } \\
\text { "” } \\
\text { ” } \\
\text { ", }\end{array}$ & $\begin{array}{l}1.038 \\
1.285 \\
1.320\end{array}$ & \begin{tabular}{l|}
$3 \cdot 64$ \\
$8 \cdot 36$ \\
$7 \cdot 15$
\end{tabular} & $\begin{array}{l}0.685 \\
0.540 \\
0.600 \\
0.796 \\
1.090 \\
1.268 \\
0.394 \\
0.589 \\
\end{array}$ & \begin{tabular}{|l|}
$7 \cdot 650$ \\
7.010 \\
6.780 \\
7.690 \\
$8 \cdot 050$ \\
8.550 \\
$9 \cdot 600$ \\
6.820 \\
\end{tabular} & 199.5 & $\begin{array}{l}272 \cdot 0 \\
252 \cdot 0\end{array}$ & + & $\begin{array}{l}1.98 \\
2.85\end{array}$ & $\begin{array}{l}37 \cdot 1 \\
19 \cdot 5\end{array}$ \\
\hline $\begin{array}{r}1 / 6 \\
16 / 6 \\
24 / 6 \\
25 / 6 \\
26 / 6 \\
28 / 6 \\
29 / 6 \\
30 / 6 \\
1 / 7 \\
2 / 7 \\
3 / 7 \\
6 / 7 \\
7 / 7 \\
\end{array}$ & 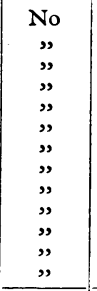 & \begin{tabular}{|l|}
$1 \cdot 15$ \\
1.25 \\
0.659 \\
0.856 \\
0.980 \\
0.612
\end{tabular} & \begin{tabular}{|c|}
$7 \cdot 3$ \\
$11 \cdot 6$ \\
$8 \cdot 0$ \\
$9 \cdot 0$ \\
$9 \cdot 15$ \\
$6 \cdot 64$
\end{tabular} & $\begin{array}{l}0.931 \\
0.601 \\
0.931 \\
0.765 \\
0.700 \\
0.702 \\
0.888 \\
0.382 \\
0.345 \\
0.798 \\
0.742 \\
0.262 \\
\end{array}$ & \begin{tabular}{|l|}
7.980 \\
$5 \cdot 460$ \\
7.350 \\
$4 \cdot 650$ \\
$2 \cdot 221$ \\
$2 \cdot 602$ \\
$2 \cdot 100$ \\
3.240 \\
1.540 \\
$4 \cdot 890$ \\
3.720 \\
$1 \cdot 165$ \\
\end{tabular} & \begin{tabular}{|r|}
124.0 \\
40.2 \\
136.0 \\
55.0 \\
157.0 \\
138.0 \\
77.9 \\
40.4 \\
\\
65.5 \\
\end{tabular} & \begin{tabular}{|c|}
188.0 \\
$101 \cdot 0$ \\
$115 \cdot 0$ \\
146.0 \\
192.0 \\
196.0 \\
100.0 \\
$102 \cdot 0$ \\
\\
105.5 \\
\end{tabular} & $\begin{array}{c}+ \\
+ \\
+ \\
+ \\
+ \\
103 \cdot 0 \\
40 \cdot 2 \\
63 \cdot 4 \\
\\
61 \cdot 1 \\
\end{array}$ & $4 \cdot 56$ & $10 \cdot 4$ \\
\hline $\begin{array}{r}8 / 7 \\
9 / 7 \\
10 / 7 \\
13 / 7 \\
14 / 7 \\
15 / 7 \\
16 / 7 \\
17 / 7 \\
20 / 7 \\
22 / 7 \\
24 / 7 \\
22 / 7 \\
29 / 7 \\
30 / 7 \\
27 / 8\end{array}$ & $\begin{array}{l}\text { Yes } \\
\text { "” } \\
\#, \\
\#, \\
\#, \\
\#, \\
\#, \\
\#\end{array}$ & $\begin{array}{l}0.436 \\
0.590 \\
0.617 \\
\end{array}$ & $\begin{array}{l}4 \cdot 78 \\
6 \cdot 17 \\
2 \cdot 45 \\
\end{array}$ & $\begin{array}{l}0.545 \\
\\
\\
0.158 \\
0.342 \\
0.700 \\
\end{array}$ & \begin{tabular}{|l|l|}
$3 \cdot 720$ \\
3.440 \\
$5 \cdot 650$ \\
$4 \cdot 260$ \\
$4 \cdot 445$ \\
$4 \cdot 420$ \\
$4 \cdot 010$ \\
$4 \cdot 920$ \\
$5 \cdot 340$ \\
$4 \cdot 350$ \\
$7 \cdot 300$ \\
$4 \cdot 010$ \\
$4 \cdot 030$ \\
$2 \cdot 460$ \\
$1 \cdot 685$ \\
\end{tabular} & $\begin{array}{l}15 \cdot 6 \\
90 \cdot 5 \\
48 \cdot 0\end{array}$ & $\begin{array}{c}61 \cdot 0 \\
99 \cdot 5 \\
\\
131 \cdot 2\end{array}$ & $\begin{array}{r}65 \cdot 5 \\
51 \cdot 5 \\
58.5\end{array}$ & 5.94 & $9 \cdot 80$ \\
\hline $\begin{array}{l}\text { Upper } \\
\text { of no }\end{array}$ & $\begin{array}{l}\text { limit } \\
\text { ormals }\end{array}$ & $<2 \cdot 0$ & $<5.5$ & $<0.283$ & $<0.04$ & $<14.0$ & $<54.0$ & - & $\left|\begin{array}{l}\text { Trace } \\
<1 \cdot 0\end{array}\right|$ & - \\
\hline
\end{tabular}


Porphyrin results (Table II): porphyrins were estimated, often daily, over three periods-before, during, and after stilboestrol.

TABLE II.-Case 2. Nine Weeks' Observation (20 February to 26 April 1964)

\begin{tabular}{|c|c|c|c|c|c|c|c|c|c|}
\hline \multirow{2}{*}{$\begin{array}{l}\text { Date } \\
1964\end{array}$} & \multirow{2}{*}{$\begin{array}{l}\text { Stilb- } \\
\text { oestrol }\end{array}$} & \multicolumn{4}{|c|}{$\begin{array}{c}\text { Urine } \\
\text { (mg./day) }\end{array}$} & \multicolumn{2}{|c|}{$\begin{array}{c}\text { Stools } \\
\left(\mu \mathrm{g} . / \mathrm{g} . \text { Dry } \mathrm{W}_{\mathrm{t}} .\right)\end{array}$} & \multicolumn{2}{|c|}{$\begin{array}{c}\text { Plasma } \\
(\mu \mathrm{g} . / 100 \mathrm{ml} .)\end{array}$} \\
\hline & & P.B.G. & A.L.A. & $\mathrm{Cp}$ & Ur & $\mathrm{Cp}$ & $\mathrm{Pp}$ & $\mathrm{Cp}$ & $\mathrm{Ur}$ \\
\hline $\begin{array}{l}20 / 2 \\
25 / 2 \\
28 / 2 \\
29 / 2 \\
3 / 3\end{array}$ & $\begin{array}{l}\text { Yes } \\
\text { " } \\
\# \\
\text { " }\end{array}$ & $\begin{array}{l}0.611 \\
2.84 \\
0.758\end{array}$ & $\begin{array}{r}7.24 \\
20.50 \\
8.25\end{array}$ & $\begin{array}{l}0.396 \\
0.249 \\
0.249\end{array}$ & $\begin{array}{l}4 \cdot 520 \\
4 \cdot 790 \\
5 \cdot 870 \\
2 \cdot 510 \\
3 \cdot 255\end{array}$ & $\begin{array}{r}163.0 \\
86.5\end{array}$ & $\begin{array}{l}506.0 \\
158.0\end{array}$ & & 16.0 \\
\hline $\begin{array}{r}9 / 3 \\
19 / 3 \\
24 / 3 \\
1 / 4 \\
3 / 4 \\
9 / 4 \\
10 / 4 \\
13 / 4 \\
14 / 4 \\
15 / 4 \\
16 / 4\end{array}$ & $\begin{array}{l}\text { No } \\
\text { "” } \\
\text { "” } \\
\text { "” } \\
\text { ", } \\
\text { "” }\end{array}$ & 1.055 & 6.90 & $\begin{array}{l}0.480 \\
0.702 \\
0.400 \\
0.383 \\
0.756 \\
0.443 \\
0.404 \\
0.388 \\
0.188 \\
0.318 \\
0.239\end{array}$ & \begin{tabular}{|r|}
6.120 \\
10.760 \\
10.350 \\
9.610 \\
10.070 \\
5.540 \\
5.550 \\
3.179 \\
2.730 \\
3.760 \\
3.890 \\
\end{tabular} & $\begin{array}{r}83.4 \\
89.0 \\
102.4\end{array}$ & $\begin{array}{r}89 \cdot 0 \\
220 \cdot 0 \\
\\
104 \cdot 0 \\
67 \cdot 1 \\
51 \cdot 5\end{array}$ & 1.0 & $\begin{array}{r}6.0 \\
5.0 \\
10.6\end{array}$ \\
\hline \begin{tabular}{l|}
$20 / 4$ \\
$21 / 4$ \\
$23 / 4$ \\
$24 / 4$ \\
$26 / 4$
\end{tabular} & $\begin{array}{l}\text { Yes } \\
\text { "’ } \\
, "\end{array}$ & 1.350 & $10 \cdot 4$ & $\begin{array}{l}0.205 \\
0.396 \\
0.446 \\
0.513 \\
\end{array}$ & $\begin{array}{l}2.527 \\
7.000 \\
3.340 \\
6.620 \\
\end{array}$ & $\begin{array}{r}112.5 \\
20.9\end{array}$ & $\begin{array}{r}104 \cdot 8 \\
74 \cdot 5\end{array}$ & 0.8 & $5 \cdot 25$ \\
\hline pe & & $<2 \cdot 0$ & $<5.5$ & $<0.283$ & $<0.040$ & $<14.0$ & $<54.0$ & $<1.0$ & 0 \\
\hline
\end{tabular}

Erythrocyte porphyrins were normal: coproporphyrin $(0.71 \mu \mathrm{g} . / 100 \mathrm{ml}$ ); protoporphyrin $(39 \cdot 2 \mu \mathrm{g} . / 100 \mathrm{ml}$.).

\section{Control Series}

The urinary, faecal, and erythrocytic porphyrin levels in six patients on long-term high-dosage stilboestrol therapy were examined (Table III). All had carcinoma of the prostate without manifestations of metastases or porphyria. They were aged $55,65,66,70,71$, and 73 at the start of treatment and had had $30-75 \mathrm{mg}$. of stilboestrol daily for two to five years.

\section{Porphyrin Investigations : Materials and Methods}

Faecal coproporphyrin and protoporphyrin and urinary uroporphyrin and coproporphyrin were determined as described by Rimington (1961). Urinary $\delta$-amino-laevulinic acid and porphobilinogen were estimated by the method of Mauzerall and Granick (1956) with Dowex 2-X8 and Dowex $50 \mathrm{~W}-\mathrm{X} 8$ respectively. Erythrocyte and plasma porphyrin determinations were based on a method described by Rimington et al. (1963), the correction formulae and constants given by Rimington (1961) for faecal porphyrin analysis being used. The results are expressed in $\mu \mathrm{g} . / 100 \mathrm{ml}$.

\section{Results}

The porphyrin estimations are presented in Tables I, II, and III.

Case 1 (Table I).-The porphobilinogen remained normal, but the urinary uroporphyrin showed some change: (1) for two months before stopping oestrogens $-7.7 \mathrm{mg}$./day (average of eight readings) ; (2) for one and a half months after stopping

\begin{tabular}{|c|c|c|c|c|c|c|c|c|c|c|}
\hline \multirow{2}{*}{ Patient } & \multirow{2}{*}{$\begin{array}{l}\text { Daily } \\
\text { Dose } \\
\text { (mg.) }\end{array}$} & \multirow{2}{*}{$\begin{array}{l}\text { Length } \\
\text { of } \\
\text { Treat- } \\
\text { ment } \\
\text { (Years) }\end{array}$} & \multicolumn{3}{|c|}{$\begin{array}{c}\text { Urine } \\
\text { (mg./litre) }\end{array}$} & \multicolumn{3}{|c|}{$\begin{array}{c}\text { Stools } \\
\text { ( } / \mathrm{g} . / \mathrm{g} . \text { Dry W/t.) }\end{array}$} & \multicolumn{2}{|c|}{$\begin{array}{l}\text { Erythrocyte } \\
(\mu \mathrm{g} . / 100 \mathrm{ml} \text {. }\end{array}$} \\
\hline & & & P.B.G & $\mathrm{Cp}_{\mathrm{p}}$ & Ur & $\mathrm{Cp}$ & $\mathrm{Pp}$ & $\mathrm{Ur}$ & $\mathrm{Pp}$ & $\mathrm{Cp}$ \\
\hline $\begin{array}{l}1 \\
2 \\
3 \\
4 \\
5 \\
5\end{array}$ & $\begin{array}{l}30 \\
45 \\
75 \\
75 \\
75 \\
75\end{array}$ & $\begin{array}{l}5 \\
4 \\
4 \\
3 \\
3 \\
2\end{array}$ & $\begin{array}{l}0.32 \\
0.58 \\
0.22 \\
0.54 \\
0.72 \\
0.35\end{array}$ & $\begin{array}{l}0.232 \\
0.049 \\
0.116 \\
0.036 \\
0.105 \\
0.063\end{array}$ & \begin{tabular}{|l|}
0.016 \\
0.099 \\
0.022 \\
0.008 \\
0.011 \\
0.004 \\
\end{tabular} & $\begin{array}{l}12.0 \\
22.8 \\
16.4 \\
16.6 \\
18.7 \\
14.7 \\
\end{array}$ & $\begin{array}{r}29 \cdot 1 \\
33.4 \\
21.0 \\
17.3 \\
8.5 \\
26.6 \\
\end{array}$ & -- & $\begin{array}{l}18.9 \\
17 \cdot 8 \\
32 \cdot 4 \\
37 \cdot 6 \\
37 \cdot 2 \\
17 \cdot 7 \\
\end{array}$ & $\begin{array}{l}0.625 \\
0.285 \\
0.252 \\
0.249 \\
0.348 \\
0.450\end{array}$ \\
\hline \multicolumn{3}{|c|}{ Unver limit of normal } & & & & & & & $<52$ & $<2.5$ \\
\hline
\end{tabular}

oestrogens- $-3.5 \mathrm{mg}$./day (average of 12 readings) ; (3) for two months after restarting oestrogens $-4.5 \mathrm{mg}$. (average of 15 readings).

Case 2 (Table II).-The porphyrin tests remained fairly constant throughout the three periods : (1) while on stilboestrol (3 weeks); (2) after stopping oestrogens (6 weeks), and (3) after restarting stilboestrol (2 weeks). Between 19 March and 3 April the urinary uroporphyrins almost doubled: we attribute this to the patient drinking sherry that had been smuggled into the ward.

Dr. Z. Roth, statistician, calculates that the pattern of the variations in Cases 1 and 2 is such that the changes cannot be attributed to the oestrogen therapy-other undiscovered factors will have been responsible.

Control Series (Table III).-No abnormality of porphyrin excretion was detected in the six patients who had taken daily oestrogens in high dosage for two to five years.

\section{Discussion}

Female sex hormones have definite but inconstant action in the acute intermittent variety of hepatic porphyria (Redeker, 1963 ; Watson, 1964 ; Welland et al., 1964). A hypothesis has been advanced to explain this (De Matteis and Rimington, 1962 ; Rimington and De Matteis, 1965). In contrast, cutaneous hepatic porphyria may be unaffected by oestrogens in spite of the hormone being metabolized by the liver (Martini, 1963). Though it is not certain whether there is an underlying genetic predisposition in alcoholic cutaneous hepatic porphyria, as has been suggested by Prato (1964), or whether it is a purely symptomatic phenomenon due to liver damage, the biochemical defect appears to be well defined and not the same as that found in other hepatic porphyrias, such as acute intermittent porphyria. For example, patients with alcoholic cutaneous hepatic porphyria metabolize glycine normally (Rasetti et al., 1962) and react adversely to chloroquine (Marsden, 1959; Cripps and Curtis, 1962; Sweeny, 1963 ; Sweeny et al., 1965).

Both our patients seemed to belong to the symptomatic variety of cutaneous hepatic porphyria because of these features: late onset, liver damage, high and prolonged alcoholic consumption, and absence of family history. The pattern of porphyrin excretion favoured the symptomatic form with considerably increased urinary uroporphyrins (100fold above the normal) and, to a less extent, increased urinary coproporphyrins. In symptomatic cutaneous hepatic porphyria the faecal coproporphyrins often exceed the protoporphyrins, with protoporphyrins below $100 \mu \mathrm{g} . / 100 \mathrm{ml}$., but in our two cases faecal protoporphyrins tended to exceed coproporphyrins. Repeated tests for occult blood in the stools were negative. The predominance. of faecal protoporphyrin over coproporphyrin might suggest features of hereditary cutaneous hepatic porphyria (Eales, 1963), though, as already stated, the family history in our patients was negative.

Normal values for faecal and urinary porphyrins range widely (Eales, 1963). The upper limit of normal faecal porphyrins reported by Rimington et al. (1963) are included in Table $\mathbf{I}$.

The previous reports that cutaneous hepatic porphyria in 10 patients had been precipitated by oestrogens are difficult to assess : three of these had the hereditary mixed variety (Watson, 1960) and clinical and biochemical details of the rest are incomplete, though possibly four (Watson, 1960; Watson et al., 1962; Wilkinson, 1963 ; Hurley and English, 1963) were alcoholic cutaneous hepatic porphyria.

Estimations of porphyrin levels in our two patients before the onset of manifestations of cutaneous hepatic porphyria were unfortunately not available, but we stopped oestrogen 
therapy for six weeks, and, as in the patient carefully studied by Walshe and Warin (1963), were unable to demonstrate any significant alteration of porphyrin excretion. Some variables, such as exposure to sunlight and the taking of alcohol and drugs, were controlled by admitting the patients to hospital. We made daily porphyrin estimations, often over several consecutive days, because isolated readings may be misleading owing to day-to-day fluctuations. In symptomatic cutaneous hepatic porphyria alcohol is a well-known precipitant (Brunsting, 1954); barbiturates and sulphonamides are probably less important (Dean, 1963), but often reports fail to distinguish between hereditary and symptomatic types of cutaneous hepatic porphyria (Eales, 1963).

The difficulties to be considered before allocating the blame for the porphyric state can be seen in the examples of acquired cutaneous hepatic porphyria due to hexachlorbenzene and other chemical poisons, in which the toxins not only appeared to initiate it but caused a prolonged or permanent disorder of porphyrin metabolism (Schmid, 1960 ; Özen, 1963; Bleiberg et al., 1964). Our two patients, and that of Walshe and Warin (1963), had had barbiturates, including thiopentone, and sulphonamides at the time of prostatectomy, and oestrogens were started shortly afterwards, but the disease did not become manifest until 1, 8, and 18 months later, so the possible effect of barbiturates and sulphonamides is difficult to assess.

As a control group we studied six patients with cancer of the prostate without metastases who were not porphyrics or alcoholics and who had had feminizing doses of oestrogens for up to five years. The porphyrin levels in the blood, urine, and faeces were normal. The only similar study is that of Theologides et al. (1964), who found no alteration in porphyrin levels in two similar non-porphyric men investigated prospectively during the first few months of oestrogen therapy.

\section{Summary}

Two chronic alcoholics developed cutaneous hepatic porphyria within a year of prostatectomy and subsequent oestrogen therapy. Oestrogens have been reported to exacerbate some varieties of porphyria. Neither of our patients had a decrease in porphyrin excretion when oestrogens were stopped.

We thank Professor C. Rimington, F.R.S., for much advice and guidance; Dr. H. J. Wallace and Dr. G. C. Wells for helping us to investigate their patients ; and Dr. Z. Roth, statistician, Department of Clinical Epidemiology and Social Medicine, St. Thomas's Hospital Medical School, who examined for us the porphyrin investigation results.

\section{REFERENCES}

Bleiberg, J., Wallen, M., Brodkin, R., and Applebaum, I. L. (1964), Arch. Derm. (Chic.), 89, 793. Brunsting, L. A. (1954). Ibid., 70, 551.

Cripps, D. J., and Curtis, A. C. (1962). Ibid., 86, 575.

Dean, G. (1963). The Porphyrias, p. 45. Pitman, London.

De Matteis, F., and Rimington, C. (1962). Lancet, 1, 1332.
Eales, L. (1963). S. Afr. F. Lab. clin. Med. 9, 126, $189,302$.

Hurley, H. J., and English, R. S. (1963). Arch. Derm. (Chic.), 88, 233. Marsden, C. W. (1959). Ibid., 71, 219

Martini, G. A. (1963). Postgrad. med. 7., 39, 205.

Mauzerall, D., and Granick, S. (1956). F. biol. Chem., 219, 435.

Özen, M. A.'(1963). New Istanbul contri. clin. Sci., 6, 65.

Prato, V. (1964). Personal communication.

Prato, V. (1964). Personal communication.

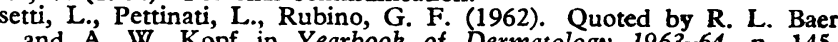
and A. W. Kopf in Yearbook of Dermatology 1963-64, p. 145. Chicago.

Redeker, A. G. (1963). S. Afr. 7. Lab. clin. Med., 9, 302.

Rimington, C. (1961). Association of Clinical Pathologists' Broadsheet, No. 36

and De Matteis, F. (1965). Lancet, 1, 270.

- Morgan, P. N., Nicholls, K., Everall, J. D., and Davies, R. R. 1963). Ibid., 2, 318

(1964). Proc. roy. Soc. Med., 57, 511.

Schmid, R. (1960). New Engl. F. Med., 263, 397.

Sweeny, G. D. (1963). S. Afr. Lab. clin. Med., 9, 302

Saunders, S. J., Dowdle, E. B., and Eales, L. (1965). Brit. med. F., 1,1281 .

Theologides, A., Kennedy, B. J., and Watson, C. J. (1964). Metabolism, 13, 391.

Walshe, M. M., and Warin, R. P. (1963). Brit. F. Derm., 75, 298.

Watson, C. J. (1960). New Engl. 7. Med., 263, 1205, 1209. (1964). Personal communication.

Runge, W., and Bossenmaier, I. (1962). Metabolism, 11, 1129.

Welland, F. J., Hellman, E. S., Gaddis, E. M., Collins, A., Hunter, G. W., and Tschudy, D. P.' (1964). Ibid., 13, 251

Wilkinson, D. S. (1963). Arch. Derm. (Chic.), 88, 233 .

\section{Medical Memoranda}

\section{Syndrome Resembling Addison's Disease Following Prolonged Treatment with Busulphan}

Brit. med. F., 1966, 1, 463-464

Busulphan is the most effective treatment in myeloid leukaemia. Toxic effects of this drug are infrequent; the most common, and one which may occur with only small doses, is excessive depression of bone-marrow. Others include hyperpigmentation of the skin (Galton, 1953 ; Haut et al., 1961), pulmonary interstitial fibrosis (Oliner et al., 1961 ; Leake et al., 1963), and a syndrome resembling adrenocortical insufficiency. This syndrome has been reported in six patients (Marinho and Martins, 1956 ; Kyle et al., 1961 ; Leake et al., 1963), in two of whom it was associated with pulmonary interstitial fibrosis and in one with chronic hyperpigmentation of the skin. This is a report of a patient in whom the syndrome resembling adrenocortical insufficiency was found with chronic skin pigmentation, pul- monary interstitial fibrosis, and heart block, an association not hitherto described.

\section{CASe Report}

A married woman was first seen in hospital in 1955 aged 63 years. She had been ill for 18 months. She was very anaemic and had a large spleen, her peripheral white blood cell count and sternal marrow examination confirmed a diagnosis of chronic myeloid leukaemia.

She was treated with busulphan and had an excellent clinical and haematological remission. She remained on maintenance doses of busulphan, and from May 1958 until her last illness in June 1963 she had been given $2 \mathrm{mg}$. every third day. During these five years her white blood count varied between 8,000 and 16,000 per c.mm. and the haemoglobin between $87 \%$ and $110 \%$. There were never more than $3 \%$ myelocytes in the peripheral blood film.

In June 1963 she was admitted to hospital weak and ill. Skin pigmentation had been present for five years. She had had increasing anorexia and had lost $46 \mathrm{lb}$. (20.9 kg.) in weight over two years. For six months more and more of her life had been spent in bed, and when she got up she frequently fainted. She had no nausea 